\title{
Confidence in results of beta-blocker postinfarction trials
}

\author{
N S BABER, J A LEWIS
}

\begin{abstract}
Seventeen published trials of beta-blockers in myocardial infarction were scrutinised for the $95 \%$ confidence limits for the reported treatment effects. All the trials were prospective, randomised, and (except when treatment was given intravenously) placebo controlled. For analysis of pooled results the trials were divided arbitrarily according to whether treatment had been given "early" or "late" after the onset of pain.

All trials were consistent with a treatment effect of just over $20 \%$, but benefit was more apparent in trials using late intervention with beta-blockers. The pooled results of trials using early intervention showed a positive effect of $8 \%$, whereas those using late intervention showed a $26 \%$ reduction in mortality and confidence limits of $17-35 \%$.

The results confirm that late intervention with betablockers after myocardial infarction reduces mortality but show that the effect of early intervention remains to be determined.
\end{abstract}

\section{Introduction}

In a previous study ${ }^{1}$ we calculated the approximate $90 \%$ confidence limits for 18 clinical trials of beta-blockers in myocardial infarction for which we could obtain adequate data. Of the 18 trials, 14 included within their confidence intervals a potential $50 \%$ reduction in mortality and 16 failed to exclude the possibility of an increased mortality with treatment. ${ }^{1}$

Since that study several further important trials have been reported, the latest being that of Hansteen et al. ${ }^{2}$ We have been regularly asked for the confidence limits for the size of the treatment effect in these later trials to add to our previous study. We therefore report our recent findings and draw attention to additional work on the pooling of the trials. Our methods, including an improved technique for calculating confidence limits, have been described. ${ }^{3}$

\section{Trials and results}

Because of earlier criticisms we studied only trials that were prospective, randomised, and placebo controlled (except for some intravenous trials) and in which 20 or more deaths were recorded. Mortality by the "intention-to-treat" principle was used. For our pooled analysis we classified trials into "early" and "late" intervention based on a 24-hour cut-off between onset of symptoms and randomisation to treatment. To some extent this division was arbitrary, as myocardial infarction is a dynamic process and many studies did not give the temporal distribution of trial admission within the stated range. Moreover, some oral trials might not be regarded as "early." Nevertheless, in practical terms a physician will want to know whether to start treatment at the time of admission (or earlier) or to wait until the acute event is past.

Seventeen published trials met our criteria. The table shows the observed percentage differences in mortality and the $95 \%$ confidence

Imperial Chemical Industries PLC, Pharmaceuticals Division, Macclesfield, Cheshire SK10 4TG

N S BABER, BSC, MRCP, medical adviser

J A LEWIS, MA, FIS, chief statistician
Percentage effect of beta-blockers on total mortality in 17 controlled trials

\begin{tabular}{|c|c|c|c|c|}
\hline $\begin{array}{l}\text { Trial } \\
\text { drug }\end{array}$ & Reference & $\begin{array}{l}\text { Lower } \\
95 \% \\
\text { confidence } \\
\text { limit }\end{array}$ & $\begin{array}{c}\text { Observed } \\
\% \\
\text { reduction } \\
\text { in mortality }\end{array}$ & $\begin{array}{l}\text { Upper } \\
95 \% \\
\text { confidence } \\
\text { limit }\end{array}$ \\
\hline \multirow{12}{*}{$\begin{array}{l}\text { Oxprenolol } \\
\text { Propranolol } \\
\text { Propranolol } \\
\text { Atenolol } \\
\text { Alprenolol } \\
\text { Propranolol } \\
\text { Propranolol } \\
\text { Practolol } \\
\text { Propranolol } \\
\text { Metoprolol }\end{array}$} & $\begin{array}{c}\text { Early trials } \\
\text { Wilcox RG, et al. Lancet 1980; }\end{array}$ & & & \\
\hline & \multirow{3}{*}{$\begin{array}{l}\text { ii } 765-9 . \\
\text { Norris RM, et al. Br Med } \mathcal{F} \\
1968 ; \text { ii: } 398-400 . \\
\text { Stephen SA (trial co-ordinator). } \\
\text { Lancet } 1966 ; \text { ii }: 1435-8 \text {. } \\
\text { Wilcox RG, et al. Br Med }\end{array}$} & -213 & -41 & 37 \\
\hline & & -117 & -30 & 22 \\
\hline & & -149 & -19 & 44 \\
\hline & $\begin{array}{c}1980 ; 280: 885-8 \text {. } \\
\text { Andersen MP, et al. Lancet }\end{array}$ & -85 & -2 & 44 \\
\hline & \multirow{2}{*}{$\begin{array}{l}\text { Andersen MP, et al. Lancet } \\
\text { 1979;ii:865-7. } \\
\text { Balcon R, et al. Lancet } 1966 \text {;ii: } \\
917-20 \text {. }\end{array}$} & -32 & 3 & \\
\hline & & & & 29 \\
\hline & \multirow{2}{*}{$\begin{array}{l}\text { Wilcox RG, et al. Br Med } \mathcal{f} \\
1980 ; \mathbf{2 8 0}: 885-8 \text {. }\end{array}$} & -82 & 3 & 50 \\
\hline & & -63 & 13 & 54 \\
\hline & \multirow{2}{*}{$\begin{array}{l}\text { Barber JM, et al. Acta Med } \\
\text { Scand } 1975 ; \text { suppl } 587: 213-9 . \\
\text { Barber JM, et al. Ulster Med } \mathcal{F} \\
1967 ; 36: 127-30 \text {. }\end{array}$} & -26 & 13 & 41 \\
\hline & & -59 & 25 & 66 \\
\hline & $\begin{array}{l}\text { Hjalmarson A, et al. Lancet } \\
1981 ; \mathrm{ii}: 823-7\end{array}$ & 4 & 36 & 57 \\
\hline \multicolumn{2}{|c|}{ Pooled early trials } & -8 & 8 & 22 \\
\hline Propranolol & \multicolumn{2}{|l|}{ Baber NS, et al. Br Heart $\mathcal{F}$ Late trials } & & \\
\hline Oxprenolol & \multirow{2}{*}{$\begin{array}{l}1980 ; 44: 96-100 \text {. } \\
\text { Hampton JR. Eur Heart f 1981; } \\
\text { 2:259-68. }\end{array}$} & -80 & -7 & 37 \\
\hline Practolol & & -40 & 14 & 46 \\
\hline \multirow{2}{*}{$\begin{array}{l}\text { Propranolol } \\
\text { Propranolol }\end{array}$} & \multirow{2}{*}{ 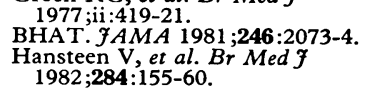 } & -3 & 20 & 38 \\
\hline & & & 2 & 4 \\
\hline \multirow{3}{*}{$\begin{array}{l}\text { Timolol } \\
\text { Alprenolol }\end{array}$} & \multirow{3}{*}{$\begin{array}{l}\text { Pedersen TR, et al. N F.ngl f } \\
\text { Med 1981;304:801-7. } \\
\text { Wilhelmsson C, et al. Lancet } \\
\text { 1974;ii:1157-60. }\end{array}$} & -12 & 31 & 59 \\
\hline & & 19 & 36 & 50 \\
\hline & & -24 & 49 & 81 \\
\hline \multicolumn{2}{|c|}{ Pooled late trials } & 17 & 26 & 35 \\
\hline
\end{tabular}

intervals. All trials were consistent with a treatment effect of just over $20 \%$, but the benefit was more apparent in late trials. This difference was statistically significant $\left(\chi^{2}{ }_{1}=4.03 ; p=0.045\right)$, which with the clinical considerations strongly supports separate analysis of the two categories of study.

The pooled results of the 10 early-entry trials showed a small positive effect (not significant) of $8 \%$, whereas the pooled results of the seven late-entry trials showed a very highly significant positive effect $\left(\chi^{2}{ }_{1}=25 \cdot 1 ; \mathrm{p}<0.00001\right)$. The percentage reduction in mortality was $26 \%$ with $95 \%$ confidence limits of $17 \%$ to $35 \%$. There was no evidence of heterogeneity of the treatment effect within either group (early $\chi^{2}{ }_{9}=7 \cdot 8$; late $\chi_{6}^{2}=5 \cdot 5$ ); hence statistically the separate results of the seven late trials were consistent with each other, as were the results of the 10 early trials.

\section{Comment}

More-detailed analysis of our findings is given elsewhere. ${ }^{3}$ Though pooling the results of studies is contentious, we believe that this was the best way to draw overall conclusions of firstorder importance from the miscellaneous collection of trials examined. Undoubtedly different beta-blockers used in different ways in different populations of patients will produce effects of different magnitudes, but we should expect these effects to be in a positive direction. It will remain difficult if not impossible to compare beta-blockers, especially in the relatively unselected groups of patients so far studied. For the present, our conclusion that "late" intervention with beta-blockers reduces mortality after infarction is amply supported both clinically and statistically. The position regarding "early"-intervention studies, 
however, is still not clear. We believe that the most encouraging area for future investigation is the use of intravenous betablockade sufficiently early after the onset of pain. ${ }^{4}$

\section{References}

${ }^{1}$ Baber NS, Lewis JA. Beta-blockers in the treatment of myocardial infarction. $\mathrm{Br} M e d \mathcal{F}$ 1980;281:59.
2 Hansteen V, Møinichen E, Lorentsen E, et al. One year's treatment with propranolol after myocardial infarction : preliminary report of Norwegian multicentre trial. $\mathrm{Br}$ Med $\mathcal{F} 1982 ; \mathbf{2 8 4}: 155-60$.

${ }^{3}$ Lewis JA, Ellis SH. A statistical appraisal of post-infarction beta-blocker trials. Primary Cardiology. Suppl No. 1. 1982.

4 Yusuf S, Ramsdale D, Peto R, et al. Early intravenous atenolol treatment in suspected acuie myocardial infarction: preliminary report of randomised trial. Lancet 1980;ii :273-6.

(Accepted 25 March 1982)

\section{SHORT REPORTS}

\section{Specificity of the immunosuppressive action of carbimazole in Graves's disease}

Carbimazole, which is rapidly metabolised on ingestion to its active metabolite methimazole, is the major antithyroid drug used in Britain for the treatment of hyperthyroidism. Its role in blocking thyroid hormone biosynthesis is well recognised. ${ }^{1}$ More recently it has become apparent that in patients with hyperthyroid Graves's disease carbimazole can influence the autoimmune process by inhibiting autoantibody production. In-vitro studies have shown that the drug can also inhibit lymphocyte antithyroid antibody synthesis at concentrations of $0 \cdot 01-0 \cdot 1 \mu \mathrm{mol} / 1(0 \cdot 1-1 \cdot 0 \mathrm{mg} / 100 \mathrm{ml}) .{ }^{2}$ Carbimazole is known to be concentrated in the thyroid but the concentrations within the gland are undetermined, though they are probably close to those shown to be immunosuppressive in vitro. ${ }^{3}$ Hence, methimazole derived from carbimazole in the circulation is probably concentrated in the thyroid and inhibits the production of thyroid antibodies by lymphocytes within the gland, which are known to be a major source of antibody production in autoimmune thyroid disease. ${ }^{4}$

The purpose of this study was to ascertain the selectivity of the immunosuppressive action of carbimazole by comparing the known effects of the drug on thyroid autoantibodies in patients with Graves's disease with those it might have on the associated but non-thyroidal gastric parietal cell antibodies in identical samples from the same patients.

\section{Patients, methods, and results}

Sera from 85 patients with hyperthyroidism due to Graves's disease (diagnosed clinically and by a diffuse thyroid scan using ${ }^{99_{\mathrm{m}} \mathrm{Tc}}$ ) collected before treatment were assessed for the presence of gastric parietal cell antibodies by immunofluorescence. The sera were graded as negative or positive for parietal cell antibodies and the positive sera were further subdivided into weak, + , and ++ . Of the 21 patients whose sera were graded ,++ 19 had at least four samples collected and available for study over the next 12 months of their management, and these 19 were chosen for the study. All received a standard regimen of carbimazole ( $45 \mathrm{mg}$ daily) for six months, which was supplemented by thyroxine $(0.15 \mathrm{mg})$ six weeks after the start of treatment with carbimazole. Coded serial samples $(n=178)$ from these 19 patients, during their course of treatment, were assayed blind for gastric parietal cell antibodies and expressed as a titre.

Thyroid-stimulating hormone receptor antibody activity was measured by a radioreceptor assay based on the ability of serum immunoglobulins to inhibit the binding of ${ }^{125}$ I-labelled thyroid-stimulating hormone to human thyroid membranes. Results were expressed as a percentage inhibition of binding of labelled thyroid-stimulating hormone relative to immunoglobulins from a pool of normal human serum (control). Previous studies indicated that inhibition of binding of thyroid-stimulating hormone of greater than $20 \%$ of control values indicated thyroid-stimulating hormone receptor antibody activity. All samples from an individual patient were studied in the same assay.

The patterns of gastric parietal cell antibodies and thyroid-stimulating hormone receptor antibody activity in identical samples from the 19 patients with Graves's disease during treatment with carbimazole were analysed by the paired Student's $t$ test and are shown in the figure.

At the start of treatment thyroid-stimulating hormone receptor antibody activity fell significantly from a pretreatment value of $62 \pm 20 \%$ inhibition of thyroid-stimulating hormone binding (mean $+\mathrm{SD}$ ) to that of $35+26$ (mean $\rfloor \mathrm{SD})$ six months later $(\mathrm{p}<0 \cdot 001)$. In contrast, gastric parietal cell antibody concentrations were not significantly altered $(p+0 \cdot 4)$ in response to carbimazole, with pretreatment $(126 \pm 315$; mean $\mathrm{SD})$ and post-treatmen $(99+203$; mean $+S D)$ values being almost identical. After treatment gastric parietal cell antibody concentrations were unchanged whereas thyroidstimulating hormone receptor antibody activity in general remained low in patients in whom relapse of the disease did not occur.

Changes in thyroid microsomal antibodies (data not shown), which, like the gastric parietal cell antibodies, are antibodies to a cytoplasmic antigen, paralleled the changes in thyroid-stimulating hormone receptor antibody activity.

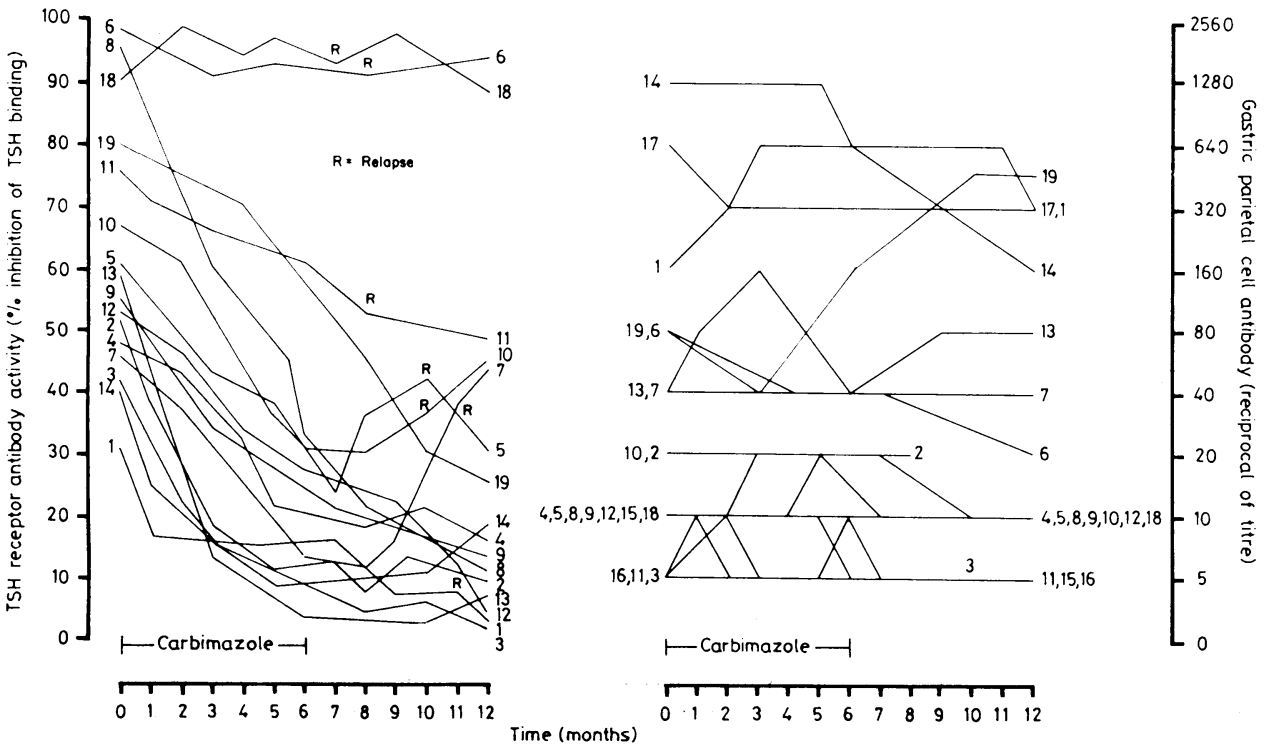

Patterns of thyroid-stimulating hormone (TSH) receptor and gastric parietal cell antibody activity in 19 patients with hyperthyroid Graves's disease treated with carbimazole. 